\title{
Edukasi “Wheel Heads-Up” sebagai Pencegahan Diabetes Melitus
}

\author{
Education of "Wheel Heads-Up" as a Prevention of Diabetes
}

\author{
Nurul Ulya Luthfiyana ${ }^{1^{*}}$, Arina Mufida Ersanti ${ }^{1}$, Elok Permatasari ${ }^{1}$ \\ ${ }^{1}$ Program Studi S1 Kesehatan Masyarakat Universitas Jember \\ *ulya.luthfiyana@unej.ac.id
}

\begin{abstract}
ABSTRAK
Diabetes melitus merupakan masalah kesehatan masyarakat yang penting, dengan jumlah kasus dan prevalensi yang terus meningkat selama beberapa dekade terakhir. Dampak penyakit diabetes melitus sangat kompleks, selain penyakit kardiovaskuler, diabetes melitus juga merupakan salah satu penyebab utama penyakit ginjal dan kebutaan pada usia di bawah 65 tahun, dan juga amputasi yang bukan disebabkan oleh trauma, disabilitas, hingga kematian. Namun, upaya pencegahan dan deteksi dini faktor risiko penyakit Diabetes Melitus masih belum optimal pada semua kelompok masyarakat. Upaya pencegahan Diabetes Mellitus ini dapat dilakukan dengan pemberikan edukasi Kesehatan kepada masyarakat dengan metode yang inovatif. Tujuan Pengabdian kepada Masyarakat ini adalah memberikan edukasi tentang pencegahan Penyakit Diabetes Melitus. Kegiatan ini dilaksanakan di Desa Suci Kecamatan Panti Kabupaten jember pada tahun 2020 dengan peserta yaitu para pejabat pemerintah desa dan Badan Permusyawaratan Desa sejumlah 23 orang sebagai sasaran utama. Metode pelaksanaan kegiatan ini meliputi penyuluhan, edukasi dengan metode permainan edukatif Wheel-Heads Up, deteksi dini faktor risiko dan pemeriksaan Kesehatan serta konseling terkait penyakit Diabetes Melitus. Hasil kegiatan Pengabdian kepada Masyarakat ini menunjukkan respon seluruh peserta yang sangat antusias dalam mengikuti kegiatan serta meningkatnya pengetahuan dan pemahaman tentang Diabetes Melitus. Diharapkan agar kader dan tenaga Kesehatan dapat memberikan edukasi Kesehatan dan deteksi dini faktor risiko penyakit secara berkelanjutan termasuk penyakit tidak menular seperti Diabetes Melitus.
\end{abstract}

Kata kunci — Diabetes Melitus, edukasi, faktor risiko

\begin{abstract}
Diabetes mellitus is an important public health issue, with the number of cases and prevalence continuing to rise over the past few decades. The impact of diabetes mellitus is very complex, in addition to cardiovascular disease, diabetes mellitus is also one of the main causes of kidney disease and blindness at the age of under 65 years, and also amputations that are not caused by trauma, disability, until death. However, efforts to prevent and early detection of diabetes mellitus risk faktors are still not optimal in all groups of people. Efforts to prevent Diabetes Mellitus can be done by providing health education to the public with innovative methods. The purpose of this Community Service is to provide education about the prevention of Diabetes Mellitus Disease. This activity was carried out in the Suci Village, Panti, Jember in 2020 with participants namely officials of the Village Government and village consultative bodies of 23 people as the main target. The method of implementing this activity includes health education, education with the educational game method Wheel-Heads Up, early detection of risk faktors and health examinations, counseling related to Diabetes Mellitus disease. The results of this Community Service activity showed the response of all participants who were very enthusiastic in participating in the activity as well as increased knowledge and understanding about Diabetes Mellitus. It is expected that cadres and health workers can provide health education and early detection of disease risk faktors on an ongoing basis including noncommunicable diseases such as Diabetes Mellitus.
\end{abstract}

Keywords - Diabetes Mellitus, education, risk faktor 


\section{Pendahuluan}

Diabetes melitus merupakan masalah kesehatan masyarakat yang penting, menjadi salah satu dari empat penyakit tidak menular prioritas yang menjadi target tindak lanjut oleh para pemimpin dunia. Jumlah kasus dan prevalensi diabetes melitus terus meningkat selama beberapa dekade terakhir. Diabetes adalah penyakit kronis serius yang terjadi karena pankreas tidak menghasilkan cukup insulin (hormon yang mengatur gula darah atau glukosa), atau ketika tubuh tidak dapat secara efektif menggunakan insulin yang dihasilkannya.

Penyakit Tidak Menular (PTM) juga menjadi salah satu masalah kesehatan yang merupakan ancaman bagi pertumbuhan ekonomi di Indonesia. Diabetes Mellitus menjadi salah satu fokus dari 4 penyakit tidak menular utama penyebab $60 \%$ kematian di Indonesia selain penyakit kardiovaskuler, kanker, dan Penyakit Paru Obstruksi Kronis. Program pencegahan dan pengendalian faktor risiko PTM telah ditetapkan pada Renstra 2015-2019 melalui strategi advokasi, kemitraan, jejaring, dan peningkatan kapasitas. Strategi 4 by 4 telah ditetapkan yaitu fokus pada 4 penyakit utama PTM dan pengendalian 4 faktor risiko utama [1].

Data Riset Kesehatan Dasar (Riskesdas) 2018 menyebutkan bahwa terjadi peningkatan prevalensi diabetes melitus dari 1.5 persen (2013) menjadi 2.0 persen (2018) pada usia 15 tahun ke atas. Provinsi Jawa Timur memiliki prevalensi diabetes yang lebih tinggi $(2.6 \%)$ dibandingkan dengan prevalensi nasional $(2.0 \%)$ pada tahun 2018. Diagnosis diabetes melitus pada usia 15 tahun ke atas di Kabupaten Jember menunjukkan peningkatan prevalensi yaitu sebesar $1.2 \%$ pada tahun 2013 menjadi $2.0 \%$ pada tahun 2018 [1,2].

Dampak penyakit diabetes melitus sangat kompleks, selain penyakit kardiovaskuler, diabetes melitus juga merupakan salah satu penyebab utama penyakit ginjal dan kebutaan pada usia di bawah 65 tahun, dan juga amputasi (yang bukan disebabkan oleh trauma) disabilitas, hingga kematian. Dampak lain dari diabetes melitus adalah mengurangi usia harapan hidup sebesar 5-10 tahun [3]. Diabetes dan komplikasinya membawa kerugian ekonomi yang besar bagi penderita diabetes dan keluarga, sistem kesehatan dan ekonomi nasional melalui biaya medis langsung, kehilangan pekerjaan dan penghasilan. Termasuk komponen biaya utama adalah rumah sakit dan perawatan rawat jalan [4]. Maka dari itu, perlu dilakukan upaya preventif Diabetes Melitus untuk meningkatkan status Kesehatan dan kualitas hidup masyarakat.

Upaya pencegahan penyakit Diabetes Melitus dapat dilakukan dengan pemberian edukasi yang berhubungan dengan faktor risiko dan deteksi dini serta upaya preventif, promotif, serta rehabilitatif yang dapat dilakukan untuk mencegah dan menangani penyakit Diabetes melitus. Deteksi dini seperti pemeriksaan kadar glukosa darah juga dapat dilakukan dalam rangka penemuan kasus lebih awal sehingga dapat dilakukan tindak lanjut yang lebih cepat [5].

Desa Suci merupakan salah satu desa di Kecamatan Panti Kabupaten Jember dengan jumlah penduduk terbanyak dengan fasilitas Kesehatan POSBINDU yang belum berjalan secara optimal sehingga paparan informasi dan deteksi Penyakit Tidak Menular (PTM) pada masyarakat termasuk penyakit Diabetes Melitus juga belum optimal [6].

Berdasarkan hal tersebut, diperlukan adanya kegiatan edukasi tentang penyakit Diabetes Melitus kepada masyarakat di lingkup instansi pada khususnya, dengan melibatkan kelompok penggerak masyarakat desa di wilayah Desa Suci, untuk meningkatkan pengetahuan dan pemahaman masyarakat tentang penyakit Diabetes Melitus. Manfaat dari kegiatan Pengabdian kepada Masyarakat ini yaitu dapat meningkatkan kesadaran dan perilaku Kesehatan masyarakat terhadap Penyakit Tidak Menular (PTM) seperti penyakit Diabetes Melitus, yang pada akhirnya dapat meningkatkan status Kesehatan masyarakat.

\section{Target dan Luaran}

Sasaran utama kegiatan Pengabdian kepada Masyarakat ini adalah para pejabat Pemerintah Desa dan Badan Permusyawaratan Desa sebagai motor penggerak masyarakat desa di Desa Suci Kecamatan Panti Kabupaten Jember sejumlah 23 orang. Bidan Desa dan beberapa kader Kesehatan sebagai ujung tombak pemantauan Kesehatan di wilayah Desa Suci juga turut berpartisipasi sehingga dapat 
mengetahui gambaran status Kesehatan di wilayah desanya serta dapat mendorong terlaksananya edukasi Kesehatan dan deteksi dini faktor risiko penyakit tidak menular seperti Diabetes Melitus secara berkelanjutan. Luaran kegiatan ini adalah sebagai berikut:

a. Meningkatkan pengetahuan dan pemahaman masyarakat tentang penyakit Diabetes Melitus

b. Mengetahui gambaran faktor risiko dan status Kesehatan masyarakat terkait penyakit Diabetes Melitus

c. Memberikan layanan konseling berdasarkan kondisi dan hasil pemeriksaan terkait penyakit Diabetes Melitus

\section{Metodologi}

Kegiatan Pengabdian kepada Masyarakat ini dilaksanakan di Desa Suci Kecamatan Panti Kabupaten Jember pada bulan SeptemberNovember 2020. Pelaksanaan kegiatan ini menggunakan metode Pendidikan dan pengukuran yang berhubungan dengan Diabetes Melitus. Metode pelaksanaan kegiatan adalah sebagai berikut:

\subsection{Penyuluhan Kesehatan}

Kegiatan ini terdiri dari beberapa tahapan, yaitu:

a. Melakukan pretest dengan mengisi 8 pertanyaan untuk mengukur pengetahuan awal tentang Diabetes Melitus

b. Penyampaian materi tentang Diabetes Melitus menggunakan media power point. Materi yang disampaikan mencakup pengertian, tipe, tanda dan gejala, faktor risiko yang tidak dapat diubah, faktor risiko yang bisa diubah, upaya deteksi dini, upaya pencegahan, dan dampak/ komplikasi Diabetes Melitus

c. Melakukan diskusi dan tanya jawab dengan peserta terkait materi yang telah disampaikan.

\subsection{Edukasi Menggunakan Metode Permainan Edukatif "Wheel-Heads Up"}

Kegiatan ini sebagai pengayaan yang terdiri dari beberapa tahapan, yaitu: a. Tim pelaksana kegiatan mencontohkan aturan permainan, yaitu melibatkan tim yang masing-masing terdiri dari 2 orang. Salah satu anggota tim berperan memutar media roda yang menampilkan sub materi Diabetes Melitus hingga berhenti dan menunjuk pada satu sub materi Diabetes Melitus, dan anggota tim lainnya mendapatkan lembar kata secara terbalik sesuai sub materi kemudian meletakkan lembar kata tersebut di atas kepala sehingga pasangan tim dapat melihat kata yang tertera pada lembar tersebut, kemudian menjawab kata berdasarkan petunjuk yang diberikan oleh pasangan timnya.

b. Memberikan kesempatan para peserta berpartisipasi aktif dalam kegiatan ini

c. Melakukan posttest dengan mengisi 8 pertanyaan untuk mengukur pengetahuan tentang Diabetes Melitus setelah pemberian materi dan pengayaan

\subsection{Skrining Diabetes Melitus} berikut:

Tahapan kegiatan ini adalah sebagai

a. Melakukan anamnesis faktor risiko Diabetes Melitus

b. Melakukan pemeriksaan antropometri yang berkaitan dengan faktor risiko Diabetes Melitus yang meliputi berat badan, tinggi badan, dan lingkar perut

c. Melakukan pemeriksaan kadar Glukosa Darah Sewaktu (GDS) dengan pengambilan darah perifer

d. Pada kegiatan ini menggunakan lembar anamnesis dan pemeriksaan untuk mendokumentasikan data

\subsection{Konseling}

Konseling diberikan sesuai kondisi atau hasil skrining Diabetes Melitus pada peserta.

\section{Pembahasan}

Peserta kegiatan Pengabdian kepada Masyarakat ini adalah para pejabat Pemerintah Desa dan Badan Permusyawaratan Desa di Desa Suci Kecamatan Panti Kabupaten Jember sebanyak 23 orang dengan hasil sebagai berikut: 


\subsection{Penyuluhan Kesehatan dan Edukasi}

Menggunakan Metode Permainan

Edukatif "Wheel-Heads Up"

Dalam rangka meningkatkan pengetahuan dan pemahaman masyarakat tentang penyakit Diabetes Melitus, peserta diberikan edukasi dengan penyuluhan dan edukasi menggunakan metode permainan edukatif "wheel-heads up" sebagai pengayaan tentang penyakit Diabetes Melitus. Kegiatan ini berjalan dengan lancar dan peserta sangat antusias dalam mengikuti kegiatan. Penyampaian materi terlaksana kurang lebih 30 menit, dilanjutkan diskusi selama kurang lebih 45 menit, serta kegiatan pengayaan menggunakan metode permainan edukatif yang disebut "Wheel-Heads Up".

Proses evaluasi (pretest dan posttest) pada seluruh peserta menggunakan lembar pertanyaan yang berisi 8 pertanyaan dengan skor total nilai maksimal 100, diisi oleh peserta secara lengkap sehingga dapat diketahui pengetahuan masyarakat tentang penyakit Diabetes Melitus yaitu meliputi pengertian, tipe, tanda dan gejala, faktor risiko yang tidak dapat diubah, faktor risiko yang bisa diubah, upaya deteksi dini, upaya pencegahan, dan dampak/ komplikasi Diabetes Melitus.

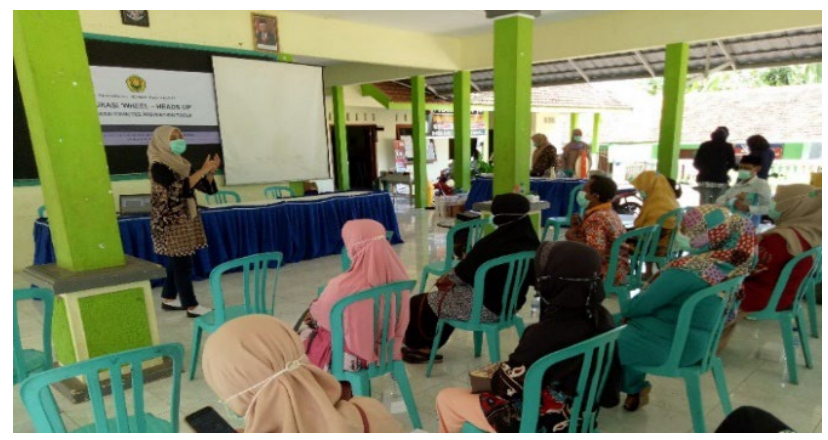

Gambar 1. Kegiatan Penyuluhan Kesehatan tentang Diabetes Melitus

Berdasarkan tabel 1 dapat dilihat bahwa hasil pre-test menunjukkan rata-rata skor pengetahuan peserta kegiatan sebelum diberikan edukasi adalah 58,2 atau termasuk dalam kategori kurang. Sebanyak 10 orang (43\%) memperoleh nilai $\leq 50$ dari total nilai maksimal 100. Hasil pre-test sebelum diberikan edukasi menunjukkan bahwa peserta pada kegiatan ini mempunyai pengetahuan yang beragam tentang penyakit Diabetes Melitus yang terlihat dari skor pengetahuan yang bervariasi, namun masih berada dalam kategori kurang.

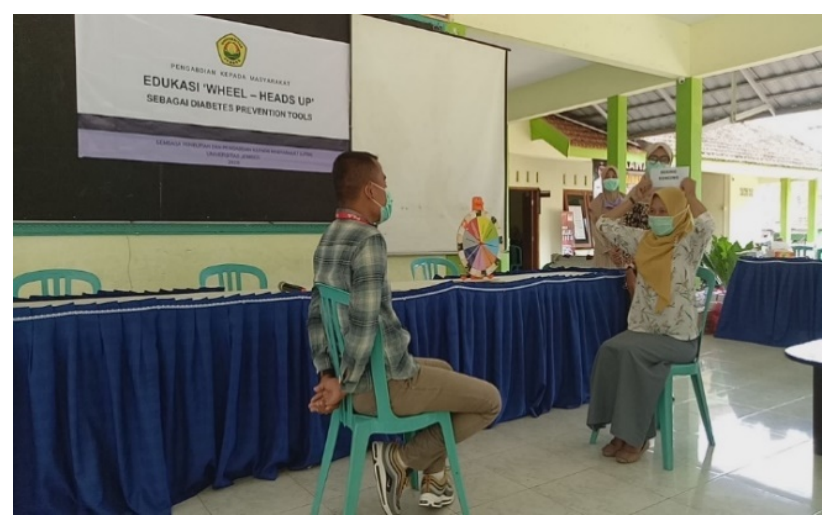

Gambar 2. Edukasi Menggunakan Metode Permainan Edukatif "Wheel-Heads Up"

Sedangkan hasil post-test menunjukkan bahwa terdapat peningkatan rata-rata skor pengetahuan peserta kegiatan setelah diberikan edukasi yaitu menjadi 89,7 atau dalam kategori baik. Pada post-test terdapat 12 orang dengan nilai tertinggi yaitu 100 (menjawab soal 100\% benar).

Selisih rata-rata skor pengetahuan tentang penyakit Diabetes Melitus sebelum mendapatkan edukasi dan setelah mendapatkan edukasi sebesar 31,6. Hal ini menunjukkan bahwa terdapat peningkatan pengetahuan peserta tentang Diabetes Melitus dengan perbedaan yang signifikan antara sebelum mendapatkan edukasi dan setelah mendapatkan edukasi. Peningkatan pengetahuan yang dimaksud dalam hal ini adalah pengetahuan tentang pengertian, tipe, tanda dan gejala, faktor risiko yang tidak dapat diubah, faktor risiko yang bisa diubah, upaya deteksi dini, upaya pencegahan, dan dampak/ komplikasi Diabetes Melitus.

Peningkatan skor pengetahuan tersebut dapat tercapai dengan adanya berbagai metode dalam pelaksanaan kegiatan yang tidak monoton yaitu penyuluhan dengan menggunakan media power point yang menarik dan diskusi interaktif antara pemateri dan peserta. Selain itu, edukasi menggunakan metode permainan edukatif "wheel-heads up" sebagai pengayaan juga sangat efektif dalam proses transfer pengetahuan. Kegiatan pengayaan dilaksanakan dengan tujuan memberikan kesempatan kepada para peserta untuk memperdalam penguasaan materi tentang Diabetes Melitus sehingga dapat tercapai tingkat 
perkembangan pengetahuan yang optimal. Kegiatan ini melibatkan para peserta secara berpasangan, metode ini secara nyata dapat meningkatkan antusiasme peserta karena menarik dan menyenangkan sehingga pemahaman secara mendalam terkait Diabetes Mellitus dapat tercapai.

Tabel 1. Hasil Pre-test dan Post-test Skor Pengetahuan pada Kegiatan Pengabdian kepada Masyarakat "Edukasi 'Wheel Heads-Up' sebagai Pencegahan Diabetes Melitus"

\begin{tabular}{llllll}
\hline $\begin{array}{l}\text { Pengukuran } \\
\begin{array}{l}\text { Skor } \\
\text { Pengetahuan }\end{array}\end{array}$ & $\overline{\mathbf{x}}$ & Med. & Min. & Max. & $\Delta$ \\
\hline Pre-test & 58,1 & 62,5 & 12,5 & 87,5 & 31,6 \\
Post-test & 89,7 & 100 & 62,5 & 100 & \\
\hline
\end{tabular}

Keterangan:

$\overline{\mathrm{x}}$ : Rata-rata

$\Delta:$ Selisih rata-rata

\subsection{Skrining Diabetes Melitus}

Kegiatan skrining dilaksanakan setelah edukasi. Peserta dilakukan anamnesis faktor risiko terlebih dahulu, kemudian dilanjutkan pemeriksaan antropometri dan pemeriksaan Glukosa Darah Sewaktu (GDS) pada pembuluh darah perifer. Hal yang menjadi fokus utama dalam kegiatan ini adalah penapisan individu dengan risiko tinggi penyakit Diabetes Melitus. Hasil dari kegiatan skrining ini menunjukkan gambaran faktor risiko dan status Kesehatan dari peserta kegiatan yang dapat dilihat pada Tabel 2 dan Gambar 4.

Berdasarkan tabel 2, menunjukkan bahwa peserta kegiatan memiliki faktor risiko penyakit Diabetes Melitus yang bervariasi baik faktor risiko yang tidak dapat diubah maupun faktor risiko yang dapat diubah. Faktor risiko Diabetes Melitus yang tidak dapat diubah seperti usia $\geq 40$ tahun dan adanya Riwayat keluarga yang menderita Diabetes Melitus. Dari peserta kegiatan ini, sebanyak 11 orang $(47,8 \%)$ berusia $\geq 40$ tahun dan 6 orang $(26,1 \%)$ yang memiliki Riwayat keluarga menderita Diabetes Melitus. Anak kandung penderita Diabetes Melitus memiliki risiko 10 kali lebih tinggi serta berisiko memiliki obesitas sentral 19 kali lebih tinggi dibandingkan individu yang tidak memiliki Riwayat keluarga penderita Diabetes Melitus. Maka dari itu, Meskipun faktor risiko ini tidak dapat diubah, upaya pencegahan yang adekuat perlu dilakukan untuk mencegah penyakit Diabetes Melitus [8].

Tabel 2. Distribusi Frekuensi Faktor Risiko Diabetes Melitus pada Kegiatan Pengabdian kepada Masyarakat "Edukasi 'Wheel Heads-Up' sebagai Pencegahan Diabetes Melitus"

\begin{tabular}{|c|c|c|}
\hline \multirow[t]{2}{*}{ Faktor Risiko } & \multicolumn{2}{|c|}{$\begin{array}{l}\text { Distribusi } \\
\text { Frekuensi }\end{array}$} \\
\hline & $\mathbf{n}$ & $\%$ \\
\hline \multicolumn{3}{|l|}{ Usia } \\
\hline$<40$ tahun & 12 & 52,2 \\
\hline$\geq 40$ tahun & 11 & 47,8 \\
\hline \multicolumn{3}{|c|}{ Riwayat Keluarga menderita DM } \\
\hline Tidak ada & 17 & 73,9 \\
\hline Ada & 6 & 26,1 \\
\hline \multicolumn{3}{|l|}{ Indeks Massa Tubuh (IMT) } \\
\hline$\leq 23 \mathrm{~kg} / \mathrm{m}^{2}$ & 15 & 65,2 \\
\hline$>23 \mathrm{~kg} / \mathrm{m}^{2}$ & 8 & 34,8 \\
\hline \multicolumn{3}{|c|}{$\begin{array}{l}\text { Lingkar Perut (Laki-laki }>90 \mathrm{~cm} \text {; } \\
\text { Perempuan }>80 \mathrm{~cm})\end{array}$} \\
\hline Tidak & 18 & 78,3 \\
\hline Ya & 5 & 21,7 \\
\hline \multicolumn{3}{|l|}{ Riwayat Penyakit Jantung } \\
\hline Tidak & 21 & 91,3 \\
\hline Ya & 2 & 8,7 \\
\hline \multicolumn{3}{|c|}{ Merokok atau Terpapar Asap } \\
\hline Rokok & 8 & 34,8 \\
\hline Tidak & 15 & 65,2 \\
\hline $\mathrm{Ya}$ & & \\
\hline \multicolumn{3}{|l|}{ Aktivitas Fisik } \\
\hline$<30$ menit/ hari & 10 & 43,5 \\
\hline$\geq 30$ menit/ hari & 13 & 56,5 \\
\hline
\end{tabular}

Sedangkan faktor risiko Diabetes Melitus yang dapat diubah seperti kegemukan, dengan IMT $>23 \mathrm{~kg} / \mathrm{m}^{2}$, Lingkar perut $>90 \mathrm{~cm}$ pada lakilaki dan lingkar perut $>80 \mathrm{~cm}$ pada perempuan, adanya Riwayat penyakit jantung, merokok atau terpapar asap rokok, dan aktivitas fisik $<30$ menit setiap harinya. Sebanyak 8 orang $(34,8 \%)$ memiliki IMT $>23 \mathrm{~kg} / \mathrm{m}^{2}, 5$ orang $(21,7 \%)$ dengan Lingkar Perut melebihi normal, 2 orang $(8,7 \%)$ memiliki Riwayat penyakit jantung, 15 orang $(65,2 \%)$ merokok atau terpapar asap rokok, dan 10 orang $(43,5 \%)$ dengan aktivitas fisik kurang yaitu kurang dari 30 menit per hari. 


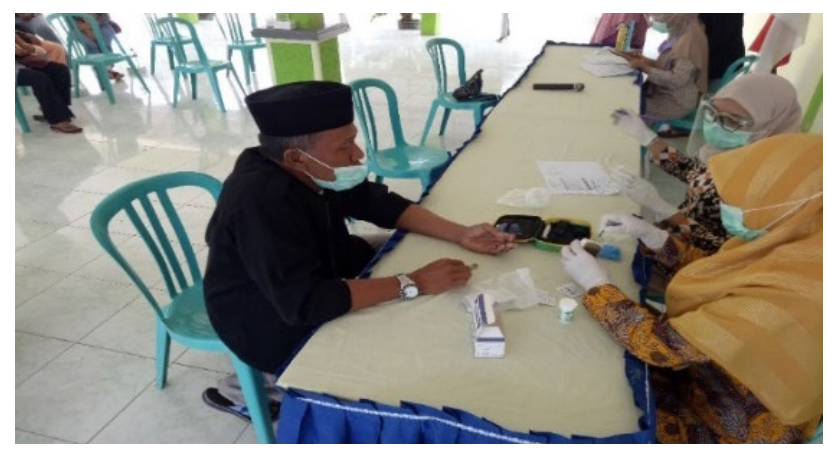

Gambar 3. Kegiatan Deteksi Dini Penyakit Diabetes Melitus

Risiko riwayat keluarga tidak dapat dimodifikasi, tetapi faktor risiko lainnya yang terkait gaya hidup dapat diubah. Termasuk faktor risiko yang dijelaskan sebelumnya, masalah berat badan dan pola tidak sehat lainnya dapat diatasi dengan pola makan sehat, rutin melakukan aktivitas fisik, mengelola stres, dan tidak mengonsumsi rokok [7].

\section{Proporsi Kadar Glukosa Darah Sewaktu (GDS)}

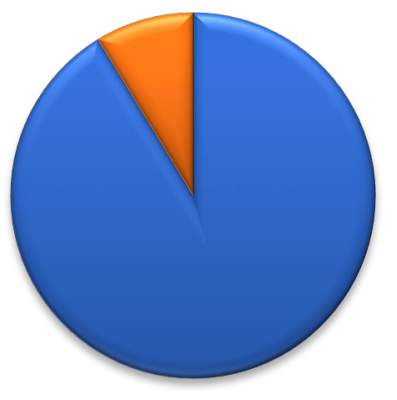

$\boldsymbol{\nabla}<200 \mathrm{mg} / \mathrm{dl} \quad \boldsymbol{\nabla}>=200 \mathrm{mg} / \mathrm{dl}$

Gambar 4. Grafik Proporsi Kadar Glukosa Darah Sewaktu (GDS) perifer Kegiatan Pengabdian kepada Masyarakat "Edukasi 'Wheel Heads-Up' sebagai Pencegahan Diabetes Melitus"

Berdasarkan Gambar 4, dapat dilihat bahwa berdasarkan hasil pemeriksaan Kadar Glukosa Darah (GDS) dengan pembuluh darah perifer sebanyak 2 orang $(8,7 \%)$ memiliki kadar Glukosa Darah Sewaktu yang melebihi nilai normal yaitu $\geq 200 \mathrm{mg} / \mathrm{dl}$, baik dengan mengalami gejala klasik seperti sering haus, sering buang air kecil, selalu lapar, maupun tidak mengalaminya. Pemeriksaan ini dapat menjadi upaya deteksi dini penyakit Diabetes Melitus sehingga upaya tindak lanjut dapat dilaksanakan secara cepat dan tepat. Tes glukosa darah dapat dilakukan secara teratur terutama bagi individu yang mendapatkan kadar glukosa darah melebihi nilai normal pada pemeriksaan sebelumnya untuk mengendalikan nilai tersebut.

\subsection{Konseling}

Setelah diperoleh hasil pemeriksaan dan mengetahui status Kesehatan peserta kegiatan, kemudian dilanjutkan dengan pemberian konseling secara personal berdasarkan faktor risiko dan hasil deteksi dini penyakit Diabetes Melitus. Pemberian konseling yang adekuat difokuskan pada upaya mencegah terjadinya penyakit DM. Peserta juga diingatkan Kembali tentang dampak/ komplikasi Diabetes Melitus yang memengaruhi fungsi mata, jantung, kulit, ginjal, saraf, dan saluran pencernaan, untuk meningkatkan awareness dan mempraktikkan upaya pencegahan Diabetes Melitus.

Peserta dengan hasil pemeriksaan risiko tinggi mendapatkan konseling adekuat dengan motivasi yang kuat terhadap individu yang bersangkutan dalam pencegahan atau pengendalian penyakit DM. Individu dengan faktor risiko rendah atau tanpa faktor risiko, juga mendapatkan konseling dan membangun komitmen yang adekuat dalam rangka mempertahankan status kesehatannya yang baik.

Berdasarkan rangkaian kegiatan Pengabdian kepada Masyarakat ini, Bidan Desa dan beberapa kader Kesehatan yang turut berpartisipasi telah dapat mengetahui gambaran status Kesehatan di wilayah desanya dan kegiatan ini dapat memotivasi dalam perumusan upaya pencegahan seperti edukasi Kesehatan dan deteksi dini faktor risiko penyakit tidak menular seperti Diabetes Melitus secara berkelanjutan.

\section{Kesimpulan}

Berdasarkan hasil pelaksanaan kegiatan Pengabdian kepada Masyarakat tentang Edukasi 'Wheel Heads-Up' sebagai Pencegahan Diabetes Melitus yang diadakan di Desa Suci Kecamatan Panti Kabupaten Jember. Masyarakat memiliki faktor risiko yang tidak dapat diubah dan faktor risiko yang dapat diubah secara variatif, hasil deteksi dini Diabetes Melitus juga menunjukkan 
bahwa masyarakat ada yang memiliki nilai glukosa darah melebihi nilai normal. Hal ini harus menjadi perhatian khusus sehingga masih perlu adanya edukasi pencegahan dan deteksi dini Diabetes Melitus. Untuk meningkatkan status kesehatan masyarakat maka terdapat rekomendasi atau saran untuk selanjutnya yaitu diharapkan agar kader atau tenaga kesehatan dapat memberikan edukasi Kesehatan dan deteksi dini faktor risiko penyakit secara berkelanjutan termasuk penyakit tidak menular seperti Diabetes Melitus serta optimalisasi POSBINDU.

\section{Ucapan Terima Kasih}

Ucapan terima kasih yang sebesarbesarnya atas bantuan, dukungan, dan Kerja sama dari pihak-pihak terkait. Pihak yang terkait dalam kegiatan ini yaitu pihak pemberi dana Hibah Internal Lembaga Penelitian dan Pengabdian Masyarakat Universitas Jember tahun 2020, serta Kepala Desa bersama pejabat Pemerintah Desa lainnya, dan Badan Permusyawaratan Desa di Desa Suci Kecamatan Panti Kabupaten Jember yang merupakan mitra kegiatan Pengabdian kepada Masyarakat ini.

\section{Daftar Pustaka}

[1] Kementerian Kesehatan RI (2018). Hasil Riset Kesehatan Dasar 2018. Jakarta: Badan Penelitian dan Pengembangan Kesehatan.

[2] Dinas Kesehatan Kabupaten Jember (2018). Profil Kesehatan Kabupaten Jember Tahun 2018. Jember: Dinas Kesehatan Kabupaten Jember

[3] Garnita D (2012). Faktor Risiko Diabetes Melitus di Indonesia (Analisis Data Sakerti 2007). Depok: FKM Universitas Indonesia.

[4] Kementerian Kesehatan RI (2012). Petunjuk Teknis Pos Pembinaan Terpadu Penyakit Tidak Menular (Posbindu PTM). Jakarta: Direktorat Pencegahan dan Pengendalian Penyakit Tidak Menular.

[5] Kementerian Kesehatan RI (2018). Strategi Pencegahan dan Pengendalian PTM di Indonesia. Diakses di http://p2ptm.kemkes.go.id/profilp2ptm/latar-belakang/strategi-pencegahan-danpengendalian-ptm-di-indonesia pada tanggal 12 Maret 2020.

[6] BPS Kabupaten Jember (2019). Kecamatan Panti dalam Angka Tahun 2019. Jember: Badan Pusat Statistik.
[7] WHO (2018).Fact Sheet of Diabetes. Diakses di https://www.who.int/news-room/facts-inpictures/detail/diabetes pada tanggal 10 Maret 2020.

[8] Kementerian Kesehatan RI (2019). Hari Diabetes Sedunia Tahun 2018. Jakarta: Pusat Data dan Informasi. 